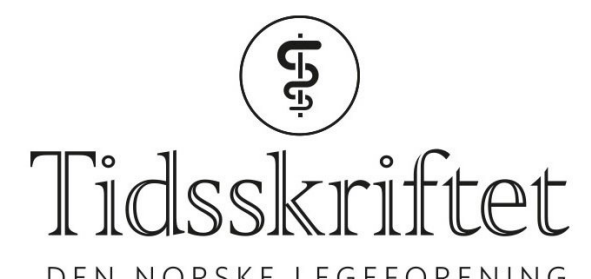

DEN NORSKE LEGEFORENING

\title{
Godt illustrert oppslagsbok i mikrobiologi
}

ANMELDELSER

\section{SILJE BAKKEN JØRGENSEN}

Smittevernoverlege, spesialist i mikrobiologi, Avdeling for mikrobiologi og smittevern Akershus universitetssykehus

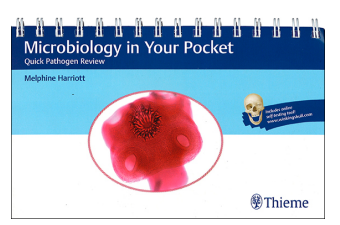

Melphine Harriot

Microbiology in your pocket

Quick pathogen review. 330 s, ill. New York, NY: Thieme, 2018. Pris EUR 45

ISBN 978-1-62623-415-4

Dette er en skjematisk repetisjonsbok for infeksjonsmedisinere og medisin- og mikrobiologistudenter. Det følger med tilgang til en nettside med illustrasjoner og animasjonsvideoer.

Rundt 140 utvalgte mikrober omtales med bilder og/eller symptomer hos en infisert pasient. I tillegg presenteres viktige kliniske poenger og beskrivelser av typiske sykdomstilfeller. Leseren får oversikt over taksonomi, patogenetiske egenskaper, smittemåte, geografisk utbredelse og naturlig habitat. Diagnostikk og behandling omtales i stikkordsform.

Boken er inndelt etter organsystemer. Innenfor hvert organsystem beskrives bakterier, virus, sopp og parasitter om hverandre, alfabetisk. For å gjøre det lettere med oppslag har sidene farger etter hva slags mikrobe som omtales.

Det er også noen tabeller med de vanligste sykdomsfremkallende bakteriene. Vi får i tillegg en oversikt over noen utvalgte dyrkingsmedier, en tabell med klinisk relevante anaerobe bakterier, virus og parasitter, samt en tabellarisk oversikt over viral hepatitt, genitale sår og vektoroverførte sykdommer.

Boken prøver ikke å dekke alle mikrober, men utvalget dekker godt de mest vanlige agens i klinisk praksis. Det beskrives en god del mikrober som ikke er vanlige i Europa, og selv om den geografiske utbredelsen til vektorbårne virus og parasitter er kort omtalt, vil det nok være utfordrende for en fersk student å skille fra hverandre hva som er vanlig og ikke. 
Opplysninger om tilgjengelige vaksiner er heller ikke nevnt.

Illustrasjonene er gode og oversiktlige, og de mange kryssreferansene er et stort pluss. For eksempel henviser arket for Bordetella pertussis til andre bakterier som produserer toksiner, og i arket om Clostridium difficile refereres det til andre sporedannende bakterier.

Det jeg savner mest er en alfabetisk oversikt over de omtalte mikrobene. I tillegg er det en svakhet at det ikke er angitt hvilke bakterier som anses som obligate patogener, og hvilke som ofte forekommer som del av en normalflora. Forfatteren understreker selv i forordet at behandlingsalternativene som oppgis kun er eksempler på midler som den aktuelle mikroben ofte er følsom for, og at dette ikke bør anses som anbefalinger i klinisk virke. Selv om tittelen indikerer at boken har lommeformat, er den alt for stor til å bæres rundt overalt. Den kan likevel fungere fint som et oppslagsverk for studenter som forbereder seg til eksamen i mikrobiologi og tropemedisin.

Publisert: 17. september 2018. Tidsskr Nor Legeforen. DOI:10.4045/tidsskr.18.0318

(C) Tidsskrift for Den norske legeforening 2020. Lastet ned fra tidsskriftet.no 